
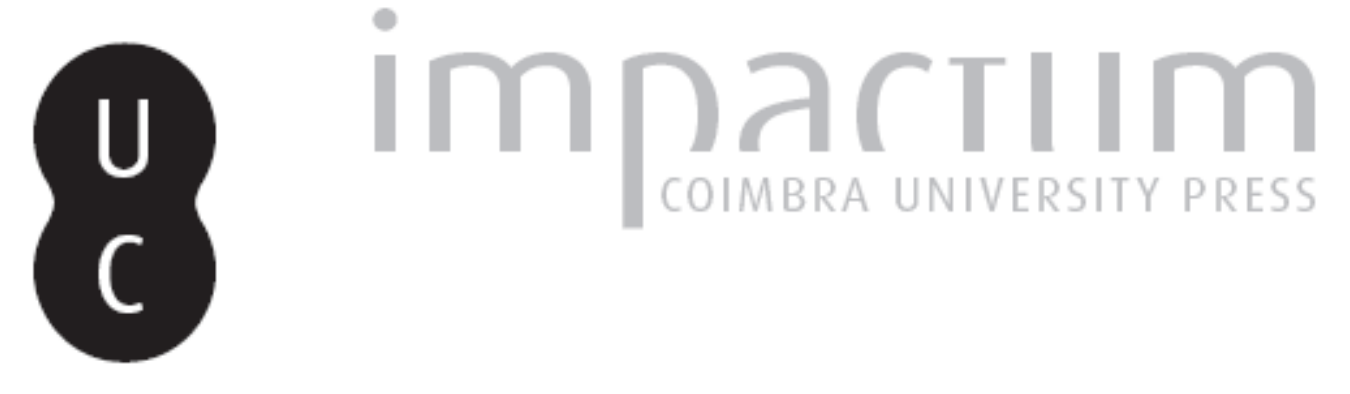

Pharmacy chains versus private pharmacies in Poland, 1989-2015

Autor(es): $\quad$ Magowska, Anita

Publicado por: Centro de Informação Europe Direct de Aveiro; Centro de Estudos
Interdisciplinares do Século XX

URL

persistente:

URI:http://hdl.handle.net/10316.2/39352

DOI:

DOI:http://dx.doi.org/10.14195/1647-6336_14_7

Accessed : $\quad$ 26-Apr-2023 15:38:28

A navegação consulta e descarregamento dos títulos inseridos nas Bibliotecas Digitais UC Digitalis, UC Pombalina e UC Impactum, pressupõem a aceitação plena e sem reservas dos Termos e Condições de Uso destas Bibliotecas Digitais, disponíveis em https://digitalis.uc.pt/pt-pt/termos.

Conforme exposto nos referidos Termos e Condições de Uso, o descarregamento de títulos de acesso restrito requer uma licença válida de autorização devendo o utilizador aceder ao(s) documento(s) a partir de um endereço de IP da instituição detentora da supramencionada licença.

Ao utilizador é apenas permitido o descarregamento para uso pessoal, pelo que o emprego do(s) título(s) descarregado(s) para outro fim, designadamente comercial, carece de autorização do respetivo autor ou editor da obra.

Na medida em que todas as obras da UC Digitalis se encontram protegidas pelo Código do Direito de Autor e Direitos Conexos e demais legislação aplicável, toda a cópia, parcial ou total, deste documento, nos casos em que é legalmente admitida, deverá conter ou fazer-se acompanhar por este aviso.

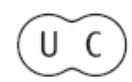


DEBATER

A EUROPA

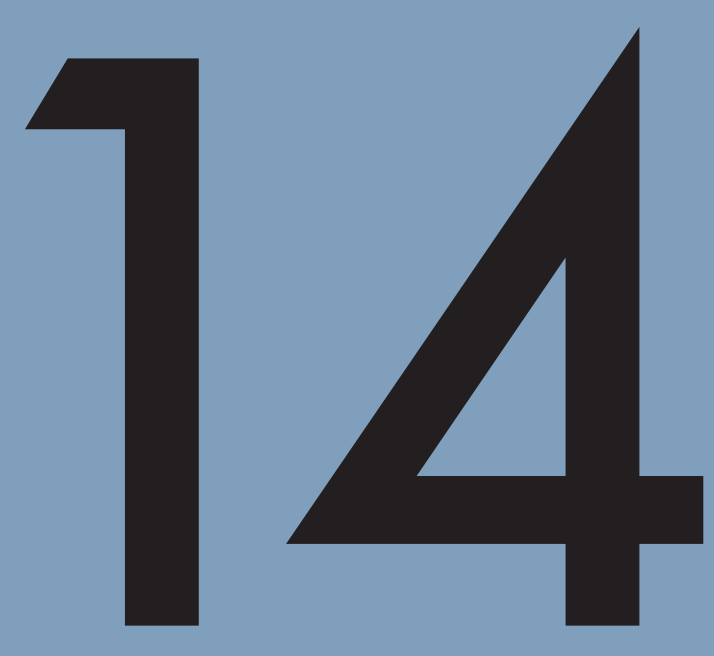

jan-jun 2016

EUROPA, FARMÁCIA, MEDICAMENTOS

EUROPE, PHARMACY, MEDICINES 


\title{
Pharmacy chains versus private pharmacies in Poland, 1989-2015
}

\author{
Anita Magowska \\ Department of History of Medical Sciences \\ Poznan University of Medical Sciences, Poland \\ E-mail: anitamagowska@yahoo.com
}

\section{Resumo}

O objetivo deste trabalho é analisar as tendências no desenvolvimento de redes de farmácias pertencentes a grossistas de produtos farmacêuticos na Polônia entre 1989-2014. Após o colapso do bloco soviético, o mercado farmacêutico polaco, como em toda a Europa Central e de Leste, seguiu os passos do mercado global e tornou-se altamente comercial. Foi uma mudança significativa uma vez que no sistema comunista o Estado detinha o monopólio sobre todos os medicamentos e outros produtos de mercado. Não havia lugar para a propriedade privada. Depois de 1989, farmácias e grossistas de produtos farmacêuticos, que foram nacionalizados em 1951, foram gradualmente substituídos por farmácias privadas e grossistas de produtos farmacêuticos. Era uma perspectiva esperançosa para os farmacêuticos. Contudo, a sua quota no mercado farmacêutico tem vindo a diminuir. Há vários fatores que contribuíram para esta situação: a falta de capital, regras desfavoráveis para o reembolso de medicamentos, legislação farmacêutica liberal, a falta de preparação para a gestão das suas farmácias e forte concorrência de cadeias de farmácias de propriedade de empresas registadas como empresas públicas. Em 2014 o mercado farmacêutico polaco estava dominado pelas redes farmacêuticas.

Palavras-chave: redes farmacêuticas; mercado global; mercado farmacêutico polaco; farmácia no século XX; grossistas farmacêuticos 


\begin{abstract}
The purpose of this paper is to analyse trends in the development of pharmacy chains belonging to pharmaceutical wholesalers in Poland in the years 1989-2014. After the collapse of the Soviet bloc, the Polish pharmaceutical market, as in all of Central and Eastern Europe, followed in the footsteps of the global market and became highly commercial. It was a significant change as in the communist system the state had a monopoly on the whole of the medicines and dressing materials market. What is more, there was no such thing as private property. After 1989, pharmacies and pharmaceutical wholesalers, which were nationalized in 1951, were gradually replaced by private pharmacies and pharmaceutical wholesalers. It was a hopeful perspective for pharmacists, but their share in the pharmaceutical market has been steadily decreasing. There are several factors that contributed to this situation: a shortage of capital, unfavourable rules for the reimbursement of medicines, liberal pharmaceutical legislation, pharmacists' lack of preparation for managing their pharmacies and strong competition from pharmacy chains owned by enterprises registered as public companies. In 2014 the Polish pharmacy market was dominated by pharmacy chains.
\end{abstract}

Keywords: pharmacy chains; global market; Polish pharmaceutical market; pharmacy in the $20^{\text {th }}$ century; pharmaceutical wholesalers

\title{
Introduction
}

In 1989 Poland freed itself from political and economic dependence on the Soviet Union and entered a period of transformation in all spheres of public life. Year by year, the domestic market for medicines and medical supplies became increasingly similar to the global pharmaceutical market. Pharmacists saw changes to be an opportunity for the revival of private pharmacies. When Poland was a member of the Eastern Bloc, the state had a monopoly not only on pharmacies, but also on supplying them and manufacturing all kinds of pharmaceuticals. Basically, no medicinal products were imported and domestic production had to suffice. All pharmacies, wholesalers and pharmaceutical factories belonged to the state, and their activity was based on government economic plans which were usually prepared once every five years (five year plan). ${ }^{1}$

\footnotetext{
${ }^{1}$ RUTKOWSKA, Elżbieta - "Aptekarze polscy wobec problemu nacjonalizacji aptek w latach 1945-1950". Czasopismo Aptekarskie. ISSN 1233-2755. 16:12 (2009) p. 31-33.
} 
An indication of economic recovery was the Economic Activity Act that came into force in 1988. On its basis pharmacists took over state-owned pharmacies that generated little profit, even though they had no experience in managing them on their own. They created small pharmaceutical wholesale outlets, ending the period of state monopoly on the distribution of medicines. ${ }^{2}$ The processes of consolidation of pharmaceutical wholesalers and the commercialization of pharmacy started in the 1990s and led eventually to a situation in which the Polish pharmaceutical market became dominated by pharmacy chains belonging to pharmaceutical wholesalers. ${ }^{3}$ The purpose of this paper is to identify the mechanisms of these changes.

\section{Pharmaceutical wholesalers and their consolidation in Europe}

The first commercial chains of pharmacies and health \& beauty stores belonging to large pharmaceutical wholesalers were opened in England at the beginning of the twentieth century. Equal work organization of pharmacies and a uniform system of supply were in line with the expectations of society and economic principles, which is why pharmacy chains dominated retail markets for medicinal products in most European countries. In the second half of the twentieth century pharmaceutical wholesalers began to merge. This led to a situation in which, for example, pharmacies in Scandinavian countries were supplied only by two or three companies. The mergers led to the creation of international companies specializing in the wholesale distribution of pharmaceutical products across the continent. These were: Gehe from Germany, known as the owner of Britain's "Lloyd's Pharmacy", British Alliance Unichem and the German company called Phoenix Tamro. In Western Europe international companies provided most of the deliveries to pharmacies, for example: in France $98 \%$ of all supplies, while in Germany and the Netherlands $60 \%$.

Medicine manufacturers also contributed to the changes taking place on the pharmaceutical market. They wanted to lower distribution costs and hired specialized companies to deliver all pre-wholesale services: logistics related to packaging, storage and the delivery of large batches of medicines to pharmaceutical wholesalers. In the course of the prewholesale services, products remained producers' properties and thus their requirements in relation to companies specializing in logistics were high. While for the pharmaceutical

\footnotetext{
${ }^{2}$ INTERNETOWY SYSTEM AKTÓW PRAWNYCH. Ustawa z dnia 23 grudnia 1988 roku o działalności gospodarczej. [21 August 2015]. WWW: <http://isap.sejm.gov.pl/DetailsServlet?id=WDU19880410324>. ${ }_{3}^{3}$ PRZYBYLSKA, Teresa - "Integracja aptekarzy - przeżytek czy pilna potrzeba?". Czasopismo Aptekarskie. ISSN 1233-2755. 15:8-9 (2008) p. 62-64.
} 
industry cooperation with just one company giving it an exclusive right to pre-wholesale was the most advantageous, the mentioned companies found it most profitable to deliver prewholesale, wholesale services and retail sales via its own chain of pharmacies. In the longer term, the manufacturers intended to build a system of delivering certain medicines directly to patients. In response to this demand the International Pharmaceutical Services Organisation (IPSO) was founded and its members included such companies as: Alliance Unichem, Sanacorp, Galenica Holding and OPG. ${ }^{4}$

IPSO sought to create a nationwide chain of pharmaceutical pre-wholesale and therefore companies belonging to it undertook efforts to enter the pharmaceutical markets of particular European countries e.g.: Gehe gained a strong position in Austria, the Czech Republic, France, Portugal, the United Kingdom and Italy, and Alliance Unichem - in France, Greece, Spain, Portugal, the United Kingdom and Switzerland. In turn, the Dutch company OPG opted for Central and Eastern Europe and in 1990 in Poland it founded an organisation called Organisation des Repartiteurs Farmaceutiques Europeens (ORFE). ${ }^{5}$

\section{Factors of the consolidation of pharmaceutical wholesalers in Poland}

During the first stage of the transformation of the Polish economy, pan-European companies engaged in pharmaceutical pre-wholesales and wholesales refrained from entering the Polish pharmaceutical market. During this period more than a thousand private pharmaceutical wholesalers were created. The experience coming from other countries showed that their mergers were inevitable. Since it took the state administration a few months to reimburse prescription medicines, pharmacies with the same delay repaid their debts to wholesalers. Each new financial burden imposed on pharmacies or wholesalers (e.g.: imposing VAT on medicines, introducing obligatory fiscal cash registers, lowering retail and wholesale margins) worsened their economic condition, reduced their working capital and accelerated the consolidation mechanism.

Private pharmaceutical wholesalers were too weak financially to maintain stability when one day profits were plummeting and others were growing. Their consolidation process reached its peak in 1998 when, on the one hand, all wholesalers experienced at least a 50\% increase in turnover, but on the other hand, the negative effects of the health care reform in

\footnotetext{
${ }^{4}$ MAGOWSKA, Anita - "Sieci aptek w Polsce. Krótka przeszłość, długa przyszłość". In MAGOWSKA, Anita - Przesztość i perspektywy farmacji. $1^{\text {st }}$ ed. Poznań: Wydawnictwo Poznańskiego Towarzystwa Przyjaciół Nauk, Wydawnictwo Kontekst, 2007. ISBN 979-83-7063-498-8, ISBN 978-88572-24-1. p. 127-138.

${ }^{5}$ DROŻDŻ, Grzegorz - "Leki dla kilku najmocniejszych". Parkiet. ISSN 1231-2207. 5:244 (1998) p. 8.
} 
Poland were clearly visible. For example, the state no longer provided certain social groups with free medicine (they used to be reimbursed by the state and so now pharmacies' turnovers decreased) and it extended the time for medicine reimbursements. The financial standing of pharmacies and wholesalers was rapidly deteriorating. Too little capital meant that half of them were not able to provide a full range of medicines, even for one day, expecting deliveries from the wholesalers twice a day and one third of pharmacies needed more frequent deliveries of medicines. ${ }^{6}$ Wholesalers took advantage of pharmacies' financial weakness and concluded with them such agreements which made pharmacies financially dependent on them. Pharmacies obliged to buy more medicines and in return wholesalers offered discounts and extended payment deadlines, thus creating a solid and loyal group of customers. In the following years, these groups significantly contributed to the commercialization process of Polish pharmacies. ${ }^{7}$

In 2003 there were almost 300 wholesalers and many of them had their own branches. ${ }^{8}$ When the number of wholesalers decreased to about a hundred, the Ministry of the Treasury started the process of privatization of the last state-owned pharmaceutical wholesalers, the so called Cefarms, which still existed in Białystok, Gdańsk, Łódź, Warsaw and Zielona Góra. Some of them were key players as they retained a large number of its own pharmacies from the communist times. For example, in Warsaw, pharmacies of the local Cefarm had a share of $7 \%$ in the medicine retail market. The ORFE Company, among others, offered to buy these companies together with their pharmacies. ${ }^{9}$

\section{ORFE as a pioneer of pharmacy chains in Poland}

The management board of ORFE has never concealed the fact that the company was set up by foreign investors, but private pharmacy owners were not afraid to compete with it for a long time. ${ }^{10}$ Initially ORFE ran its own customs bonded warehouses and specialized in pre-wholesale services for western pharmaceutical companies, including Eli Lilly and

\footnotetext{
${ }^{6}$ JANUSZEWSKA, Joanna - "Jak nie zbankrutować?". Czasopismo Aptekarskie. ISSN 1233-2755. 12:5 (2005) p. 50-53.

${ }^{7}$ FARMASKOP - "Badanie wizerunku hurtowni”. Czasopismo Aptekarskie. ISSN 1233-2755. 7:Special Issue (2000) p. 14.

${ }^{8}$ ANONYMUS - "Aptekarski Serwis Prasowy". Czasopismo Aptekarskie. ISSN 1233-2755. 11:1 (2004) p. 14.

${ }^{9}$ MAGOWSKA, Anita - "Sieci aptek...", p. 129-130.

${ }^{10}$ SUCHOCKA, Łucja - "Rynek dystrybucji w przededniu zmian”. Czasopismo Aptekarskie. ISSN 1233-2755. $12: 12$ (2005) p. 16-24.
} 
Schering. Three years after registering in Poland, the company recorded a turnover of approximately USD50 million and was transformed into a joint stock company. ${ }^{11}$

In 1997 ORFE S.A. began to create its own system of wholesale and retail distribution of medicinal products. First it took over the pharmaceutical wholesaler, Aflopa S.A., with its base in Pabianice and branches in Bielsko-Biała, Radom and Wroclaw. After the takeover, branches in Gdańsk, Katowice and Lublin were opened. Shortly after the take-over, the Łódźbased Cefarm was offered for sale to the Governor of the Łódź Province, an office held by Mirosław Marcisz (from a left wing party). However, the transaction could not be finalized before parliamentary elections, after which Marcisz lost his position and became the president of Aflopa. According to journalists, Marcisz's career and data in the ORFE prospectus pointed to the involvement of former activists of the communist party in the privatization of the Polish pharmaceutical market. A close associate of the leader of the Polish communist party in 1977-1980 sat on the supervisory board of ORFE. The management board included another activist of the party, who worked in the Council of Ministers Office in 1981 when martial law was declared, and in 1987-1990 he studied at the Diplomatic Academy in Moscow. $^{12}$

When ORFE went public on the Warsaw Stock Exchange in 1999, a controlling interest in it was acquired by Orphe Holdings LTD, a company incorporated in Malta and a subsidiary of the Dutch company OPG Deelnemingen International B.V. The latter was in turn controlled by a company called OPG Groep N.V. ${ }^{13}$ From that point, ORFE's development accelerated as the company purchased Cefarm businesses in Katowice, Rzeszów and Zielona Góra from the State Treasury. A professional organization for pharmacists, together with the Cefarm wholesale outlet employees and some Members of Parliament were against those transactions. During the privatization process, the Cefarm employees strongly supported a wholesaler called Polska Grupa Farmaceutyczna (Polish Pharmaceutical Group) as a strategic investor, but the administrative authorities were in favour of ORFE S.A. When in 2001 ORFE S.A. took over Dr. Pokorowski S.A., a pharmaceutical wholesaler based in Bydgoszcz, which had operated on the market for 10 years and which had branches in

\footnotetext{
${ }^{11}$ SZAL, Bożena, SZUKIEL, Wiktor - "Rodzina ORFE w wielkim świecie aptekarzy". Czasopismo Aptekarskie. ISSN 1233-2755. 6:12 (1999) p. 6.

${ }^{12}$ LUFT, Robert - "Bitwa o polskie apteki". Życie. ISSN 1427-177X. 4: 101 (1999) p. 11.

13 JEDLIŃSKI, Marek - "OPG zyskała na przejęciu ORFE". Prawo i Gospodarka. ISSN 1429-3471. 4:51 (2000) p. 26.
} 
Gdańsk, Piła, Legnica and Warsaw, and affiliated by capital with CORMAY Poland S.A., ORFE S.A. operated almost entirely in Poland. ${ }^{14}$

New legislation introduced in 2002 prohibiting pharmacies from combining wholesale and retail sales and holding more than $1 \%$ of all pharmacies in one province, did not impede the development of pharmacy chains belonging to the ORFE S.A. Group of Companies. ORFE focused on the development of its own chain of pharmacies in the pharmaceutical wholesalers that it had taken over. One of those companies was Cefarm Rzeszów S.A., which in 2003 ceased wholesale activities and focused on managing its own chain of pharmacies that it had held since communist times, and which were located in eighteen towns of southern Poland. In addition, subsidiaries were set up to engage in the wholesale or retail sales of medicines. The ORFE S.A. Group of Companies was thus becoming a more complex, multilayered structure, which consisted of a variety of joint-stock companies or limited liability companies. In 2004 it consisted of 21 companies, including nine consolidated subsidiaries. The complexity of their relationships is well shown by Cefarm Rzeszów S.A, which held all the shares in seven limited liability companies. These included: Cefarm Rzeszów, Farma with its seat in Rzeszów, Farma with its seat in Warsaw, Quantum Pharmacia, Pharmacy Medifarma, Vita, and Farm 3 with its base in Przemyśl. Complex capital ties were favourable for operational activities, such as transactions, providing mutual guarantees, including loan guarantees. ${ }^{15}$ Operating in this way, Grupa Kapitałowa ORFE S.A. gained about $7 \%$ of the shares in the domestic market of medicinal product distributors. ${ }^{16}$

The history of a company called Medycyna i Farmacja sheds interesting light on the mechanisms of the development of pharmacy chains in Poland. In 2002, fearing that the newly prepared amendment to the pharmaceutical legislation would prevent the Warsawbased Centrala Cefarm (then still a state enterprise) from running its nine pharmacies, the company's manager at the time, Andrzej Radzio, set up a limited liability company, Medycyna i Farmacja. The company had a minimal founding capital of PLN 4,000 (then about EUR 1,300), which was later increased to more than PLN 3,000,000 by an in-kind contribution in the form of pharmacies that had belonged to Centrala Cefarm. The inaccurate valuation of these pharmacies, arbitrary waiver of licenses for their operation and the fact that

\footnotetext{
${ }^{14}$ MAGOWSKA, Anita - "Sieci aptek...", p. 131.

${ }^{15}$ GRUPA KAPITAŁOWA ORFE S.A. - "Sprawozdanie finansowe za okres 31 grudnia 2004 r. - 30 czerwca 2005 r.”. Monitor Polski B. ISSN 1233-4502. [27 December 2006]. WWW: $<$ http://www.monitorb.pl/1513,monitor-polski-b,4715,tl.html>.

${ }^{16}$ BURZA, Piotr - "Farmaceuci w kleszczach". Gazeta Prawna. ISSN 1232-6712. 9:187 (2003) p. 11.
} 
the State Treasury lost control over Medycyna i Farmacja, which was created on the basis of the state-owned assets, were reasons for the Fiscal Inspection Office to start an investigation. Despite an unclear situation, three years later the State Treasury agreed to sell shares in Medycyna i Farmacja to Centrala Cefarm. These shares were then purchased by Cefarm Śląski, a company from Grupa Kapitałowa ORFE S.A. which was responsible for the retail market of medical products. In the same year the Group bought from the State Treasury another stake in Cefarm Zielona Góra and took over Farmacja Kolejowa from the State Railways. This is how the process of creating a chain of 168 pharmacies was completed. ${ }^{17}$

At the end of 2005, a year after Poland had joined the European Union; the Dutch OPG group started the purchase of a minority interest in ORFE. A year later, the ORFE management board revealed that it represented Alloga, a European chain of pre-wholesale companies, and announced a merger of Grupa Kapitałowa ORFE S.A.and ACP Pharma SA, thus consolidating pre-wholesale and wholesale within one company. The Chairman of the ORFE management board also announced that he would seek to limit the number of pharmacies in Poland, obviously meaning private pharmacies. ${ }^{18}$

\section{Polska Grupa Farmaceutyczna as a founder of pharmacy chains}

In 1998 the shareholders of a joint stock company called Medicines in Łódź decided to merge with other wholesalers: Carbo Katowice S.A. and Cefarm B in Opole. It was about transferring their assets to Medicines, and thus making it issue new shares. When the merger was registered in the courts, the company adopted the name Polska Grupa Farmaceutyczna (PGF), having at that time a share of $15 \%$ in the pharmaceutical market. A year later, PGF took over Urtica, a wholesaler in Wrocław, which had branches in eight Polish cities and which specialized in supplying medicines to hospitals. In the following years PGF took over, among others: Cefarms in Bydgoszcz, Kraków, Lublin, Olsztyn and Poznań, as well as the wholesalers: Biomedic Kielce, Opole Carbo, Carbo Tarnów and Aesculapius Łomża.

When PGF purchased all of the shares in Apteki Polskie (managing a chain of pharmacies called Apteki 21) and $81 \%$ of the shares in Cefarm Łódź from Enterprise Investors, it became a domestic market leader for the wholesale and retail distribution of medicines. The company had then about 300 pharmacies, i.e. 3\% of all Polish pharmacies. All

\footnotetext{
${ }^{17}$ JANUSZ, Józef - "Jak legalnie przejąć 3 miliony”. Prawo i Gospodarka. ISSN 1429-3471. 4:139 (2002) p. 89.

${ }^{18}$ STACHNIK, Andrzej - "Grupa ACP, czyli integracja przedhurtu i hurtu farmaceutycznego". Czasopismo Aptekarskie. ISSN 1233-2755. 13:10 (2006) p. 21-24.
} 
of the acquired wholesale outlets had a unified logistics and IT system introduced, and in Łódź, Krakow and Lublin modern warehouses for medicinal products were built. ${ }^{19}$

All this was against the recently amended pharmaceutical legislation. However, when the Provincial Pharmaceutical Inspection in Katowice accused PGF of acting against the legislation by having an excessive number of pharmacies in one province (province administrative territory in Poland), Baker \& McKenzie a law firm obtained the opinions of pharmaceutical inspectors from other provinces, showing that you cannot deprive anyone of the powers which had been awarded before a new piece of legislation came into force. And so, all amended regulations which were prepared by pharmacists with great effort proved to be just a piece of paper, a regulation that was easy to circumvent. ${ }^{20}$

A partnership program called "Dbam o zdrowie" (I take care of my health) proved to be PGF's success. By the end of 2006 it included more than fifteen hundred pharmacies and about one and a half million patients. The owners of pharmacies who undertook to buy medicines from PGF became its partners. Patients in the "Dbam o zdrowie" program provided pharmacists implementing the project with their personal data and registered themselves in their pharmacies. For making purchases they were rewarded prizes in the form of personal care products, vitamins, etc. They could receive a free magazine "Dbam o zdrowie", issued by PGF, and pay for purchases with a special credit card. With time, a special company was established to manage the program. It was widely advertised on television and popular among the owners of private pharmacies, who were unaware of the loss of their independence as the pharmacists who joined the program could not withdraw from it. If they did, and if they stopped buying products from PGF, their customers or patients would be taken over by the entities associated with the program. Thanks to this program, the actual chain of PGF pharmacies consisted not of 300, but of 1,500 officinae sanitatis.

Four years later PGF, controlled by Jacek Szwajcowski, holding a block of shares carrying $31 \%$ of the shares at the General Meeting of Shareholders, and Zbigniew Molenda having $15 \%$, attracted the interest of pan-European distributors of medicines: Gehe and Alliance Unichem. In October 2006 the PGF management board commissioned Rothschild Corporate Finance to prepare and conduct the sale of securities by minority shareholders. ${ }^{21}$ Currently PGF operates as the Pelion Healthcare Group. The company remains one of the leaders in the pharmacy market in Poland. It owns approximately 1,000 pharmacies and a

\footnotetext{
${ }^{19}$ MAGOWSKA, Anita - "Sieci aptek...", p. 133.

${ }^{20}$ TOMCZYK, Andrzej - "Z minionego miesiąca". Czasopismo Aptekarskie. ISSN 1233-2755. 8:4 (2001) p. 6.

${ }^{21}$ MAGOWSKA, Anita - "Sieci aptek...", p. 133-134.
} 
chain of health \& beauty stores called Natura. The company has more than 70,000 $\mathrm{m} 2$ of warehouse space and sells an average of 1.3 million packages of medicinal products a day. ${ }^{22}$

\section{Other pharmacy chains}

The growing profitability of retail sales led to a situation where listed companies chose their own pharmacies and retail sales over wholesales. One example is a company called Farmacol which has been listed on the Warsaw Stock Exchange since 1999. After the acquisition of Cefarm, Farmacol closed down wholesales and focused on a more profitable venture i.e. running 54 pharmacies of the company (at that time Farmacol had almost 150 pharmacies). Withdrawing from wholesales and focusing on maximizing its own profits coming from pharmacies was also a development strategy of the privatized wholesalers Cefarm, whose main shareholder was still the State Treasury.

It should be added that for many years Farmacol developed thanks to the so-called supported employment enterprise status that it had obtained, which meant it hired people with disabilities. This status allowed for obtaining low-interest loans from the State Fund for the Development of Disabled Persons. When the Polish pharmacy and pharmaceutical wholesalers market was being consolidated, Farmacol, as a listed company, took over seven companies, focusing on pre-wholesale services, running their own pharmacy chains and making deliveries to hospitals. Farmacol introduced its own system of settlements with pharmacies offering them discounts, which were reimbursed by medicine manufacturers in the following months. ${ }^{23}$

Very small pharmacy chains were also created. In 2003 a chain of self-service pharmacies, known in Canada and Israel as Super-Pharm, was registered in Poland. It was founded by a Canadian pharmacist Murray Koffler, and over time it became a corporation with about a thousand pharmacies. The first Super-Pharm pharmacies in Poland were opened in Szczecin, Torun and Wrocław. Anyone who on the opening day spent PLN 20 in SuperPharm received a cup of popcorn and a cinema ticket. ${ }^{24}$

Similar to chain pharmacies are supported pharmacies, which were created, among others, by Cefarm in Warsaw. They were opened within the so called investment trusts, where pharmacists were provided with money to open a pharmacy, which was formally private, but

\footnotetext{
${ }^{22}$ RUDKE, Maciej - "Neuca faworyzowana wśród dystrybutorów leków". [3 July 2015]. WWW: $<$ http://www.parkiet.com/search.html?query=notowania+pelionu\&searchType=simple $>$.

${ }^{23}$ MAGOWSKA, Anita - "Sieci aptek...", p. 134.

${ }^{24}$ OLESIŃSKI, Rafał - "Apteka i drogeria w jednym". Gazeta Prawna ISSN 1232-6712. 9:248 (2003) p. 12.
} 
actually it belonged to the company. Although many such pharmacies were created, it is difficult to estimate their number. ${ }^{25}$

\section{Independent pharmacies and pharmacy chains}

A self-government body of pharmacists and the Union of Pharmacy Owners tried to stop the process of creating chains of pharmacies in Poland, but to no avail. An amendment to pharmaceutical legislation introduced in 2002 was not effective either. Pharmacy chains were formed on the basis of commercial law and antitrust regulations limiting the concentration of capital were too weak to stop it. The initiatives of pharmacy owners were not successful because the listed companies with huge capital that ran pharmacy chains commissioned law firms to prepare an interpretation of the provisions which were favourable to them, for example: that the law could not be applied retroactively, or that there are no implementing provisions to a given regulation. It was not possible to prevent listed companies from buying companies running a few or over a dozen pharmacies. Pharmaceutical inspectors could not do anything and therefore the owners of private pharmacies tried to defend themselves on their own. They organized actions involving refraining from purchasing in warehouses which had their own pharmacies. They formed groups of pharmacies, created loyalty programs to attract clients and patients, e.g.: by using price promotions of selected over-the-counter medicines. ${ }^{26}$

As competition from chain pharmacies was strong, owners of private pharmacies focused on developing their own wholesalers, purchasing groups and pharmacy cooperatives. The Polish Supreme Pharmaceutical Council announced 2005 as a "Year of Pharmacy Wholesalers" promoting those distributors who did not have their own pharmacies. These included Torfarm S.A., founded in 1990, with the status of a supported employment enterprise since 1993, a public company since 1994 and a listed company since $2004 .{ }^{27}$

Yet, the pharmaceuticals wholesalers that were so much praised by pharmacists contributed to the commercialization of the Polish pharmaceutical market. In 2005 Torfarm S.A. launched a program called the MultiAptekaSystem which managed the advertising space in pharmacies. Then it took over small pharmaceutical wholesalers but did not invest in their development, it only rented their warehouses. It applied rigid rules for billing, charging the

\footnotetext{
${ }^{25}$ ANONYMUS, - "Spis aptek patronackich". [10 September 2015], WWW: $<$ http://www.aptekipatronackie.pl/apteki/dolnoslaskie/10-features>.

${ }^{26}$ MAGOWSKA, Anita - "Sieci aptek...", p. 135.

${ }^{27}$ GRZYWOCZ, Franciszek - "Problemy konsolidacji hurtowni aptekarskich". Czasopismo Aptekarskie. ISSN 1233-2755. 13:8-9 (2006) p. 20-22.
} 
owners of pharmacies interest on the late repayment of debts. Torfarm S.A. focused on prewholesales. Through a subsidiary called Pretium Farm it offered the owners of pharmacies 2,200 medicinal products at prices reduced by manufacturers. It ceased to have any wholesale margin and the only profit it had was a 1-2\% discount granted by pharmaceutical companies. In 2010 the Neuca Group S.A. was founded and Torfarm became one of its ten pharmaceutical wholesalers. Three years later, Neuca Med was founded. It managed a network of medical clinics specializing in primary health care. ${ }^{28}$

Purchase groups proved to defend the interests of Polish pharmacists. Most of such groups were formed in the eastern regions of Poland and in Silesia. Thanks to them it was the number of independent pharmacies and not chain pharmacies that increased. ${ }^{29}$

\section{Pharmacy market in Poland in recent years}

The pharmacy market in Poland is characterized by a steady increase in value and chain pharmacies contribute to it. In 2005 in Poland, there were 11,900 pharmacies available to the general public, of which $90 \%$, that is about 10,700 belonged to independent pharmacists or were called mini-chains, groups of not more than nine private pharmacies. The chains consisting of 5-20 pharmacies constituted almost 4\% of all pharmacies, and those consisting of over 20 pharmacies - 20\%. This year in Poland there are 90 pharmacy chains with foreign capital. For a comparison, last year there were 35 such chains. ${ }^{30}$

In 2014 in Poland there were 14,277 pharmacies available to the general public, of which slightly more than 9,700 belonged to independent pharmacists, and about 4,500 were chain pharmacies. The number of online pharmacies was increasing rapidly while the number of pharmacies owned by independent pharmacists was declining. In the first nine months of this year independent pharmacists closed 360 pharmacies and opened 230, while pharmacy chains closed 180 pharmacies and opened 581. In addition, more than 500 pharmacies changed ownership. In most cases independent pharmacies were taken over by wholesalers having their own pharmacy chains.

In Poland in 2014 there were 330 pharmacy chains which together owned more than 4,500 pharmacies and this translated into a market share of $31.8 \%$. Eleven of the largest

\footnotetext{
${ }^{28}$ RUDKE, Maciej - "Chodzi o przełomowe rozwiązania". [2 March 2015]. WWW: $<$ http://www.parkiet.com/search.html?query=akumuluj+torfarm\&searchType=simple>.

${ }^{29}$ JAKUBIAK, Luiza - "IMS: sieci rosną w siłę kosztem aptek indywidualnych". [20 November 2015] WWW: $<$ http://www.rynekaptek.pl>.

${ }^{30}$ Statistical Yearbook of the Republic of Poland. Ed. DMOCHOWSKA, Halina. ISSN 1506-0632. Vol. 57 (2014) p.267. [20 November 2015] WWW: http://www.stat.gov.pl.
} 
chains, those with more than 50 pharmacies, owned in total 1,560 pharmacies and that translated into a market share of 14\%. For comparison, a year earlier in Poland there were 566 pharmacy chains with a market share of $28.1 \%$ but there were only five chains which owned more than 50 pharmacies. The largest wholesalers and medicine distributors in 2014 were companies listed on the stock exchange: Neuca, Pelion and Farmacol. Neuca showed the greatest development potential and Pelion the smallest one. ${ }^{31}$

The development of pharmacy chains did not translate into the better accessibility of pharmacies. While in 2005 in Poland for every 10,000 residents there were 3.55 pharmacies in urban areas and 1.79 in rural ones, in 2013 (data from 2014, not available) we had 4.41 and 2.13 pharmacies respectively. At that time, the statistical number of pharmacists in cities increased by 2.1 , while in rural areas only by 0.4 . Pressure from the government to sell cheap generic medicines and lower the price of patented medicines was a powerful factor leading to changes on the Polish pharmaceutical market. In this situation, pharmacy chains are even a greater threat to independent pharmacies because they can offer lower prices for medicines. ${ }^{32}$

The decision of the Provincial Administrative Court in Warsaw of 23 July 2015 may be crucial for the further development of pharmacy chains in Poland. It supports the pharmacists' arguments that pharmaceutical legislation should prevent the cartelization of the pharmacy market in Poland. The court pointed out that the current pharmaceutical legislation does not permit any company to open another pharmacy, if the number of the pharmacies run in the given province exceeds $1 \%$ of the total. And in particular it does not permit any company to have more than $1 \%$ of all pharmacies in a particular province after a license has been issued. After the verdict it was clear that pharmacy chains have built their strong position on the market thanks to well-educated staff, highly professional operations and the low prices of medicines, but also through continuous violation of the antitrust law. The court judgment being in favour of the pharmacists was a pleasant surprise both for the pharmacists and for the professional organization for pharmacists. Probably it is not a coincidence that the courts issued such a verdict in a situation when Poland's political scene was changing. When the Civic Platform was a governing party, pharmacy chains dominated the pharmacy market as they misinterpreted pharmaceutical legislations and regulations on competition protection. In the autumn of 2015 a right-wing party, Law and Justice, won the elections and the owners

\footnotetext{
${ }^{31}$ JAKUBIAK, Luiza - "IMS: sieci...".

${ }^{32}$ MAC, Jerzy - "Raport: na polskich wsiach jest za mało aptek". [9 November 2015]. WWW: $<$ http://www.rynek.aptek.pl>.
} 
of small pharmacies hope that it will improve their situation. The new government promised to support small businesses so the antitrust law should be respected ${ }^{33}$.

\section{Conclusions}

Polish pharmaceutical legislation was liberalized during the political and economic transformation that took place in Poland. As commercial law was given primacy over pharmaceutical legislation, public administration lost control of the pharmacy market, especially over the sale of over-the-counter medicines. The Ministry of the Treasury and provincial governors enabled the inflow of foreign capital to pharmaceutical wholesalers. The division of the pharmacy market between several large listed companies led to its greater commercialization, among other things through an increase in sales of over-the-counter medicines. In recent years pharmaceutical legislation has been bent to the interests of companies running pharmacy chains. Meanwhile, pharmacy chains operate against the principles of public health as they use promotional methods that lead to the greater consumption of medicines.

Not only did pharmacy chains contribute to the commercialization of the pharmaceutical market but they also undermined customer's confidence in pharmacists. After the recent presidential elections in Poland and a right-wing party coming to power, judicial decisions relating to pharmacy chains have changed. As mentioned above, the Provincial Administrative Court in Warsaw decided that running more than $1 \%$ of all pharmacies in one province is against pharmaceutical legislation. It could be a turning point.

Artigo Recebido a 29 de novembro de 2015 I Aceite a 06 de março de 2016

\footnotetext{
${ }^{33}$ SĘDLAK, Piotr - ”Jeden procent, czyli zdrowy rozsądek ma tylko jedną twarz". [9 November 2015]. WWW:<http://www.rynekaptek.pl>.
} 